\title{
KONSEP DIRI, LINGKUNGAN KELUARGA DAN KEDISIPLINAN SISWA BERPENGARUH TERHADAP HASIL BELAJAR MATERI AKUNTANSI SISWA KELAS XI JURUSAN IPS, SMA ANTARTIKA SIDOARJO
}

\author{
Fransiska Rista Andriani, Universitas Negeri Surabaya \\ aa_frista87@yahoo.co.id
}

\begin{abstract}
ABSTRAK
Penelitian ini bertujuan untuk menganalisis pengaruh konsep diri, lingkungan keluarga dan kedisiplinan terhadap hasil belajar materi akuntansi siswa secara parsial maupun simultan. Populasi dalam penelitian ini adalah siswa kelas XI jurusan IPS SMA Antartika Sidoarjo tahun ajaran 2013/2014 sebanyak 180 orang, sedangkan jumlah sampel yang digunakan sebanyak 124 orang. Adapun teknik pengumpulan data yang digunakan yaitu angket, wawancara, dan dokumentasi. Metode analisis menggunakan Teknik Regresi Linier Berganda. Hasil penelitian menunjukkan bahwa konsep diri tidak berpengaruh terhadap hasil belajar. lingkungan keluarga dan kedisiplinan berpengaruh signifikan terhadap hasil belajar. Konsep diri, lingkungan keluarga, dan kedisiplinan secara simultan mempunyai pengaruh nyata terhadap hasil belajar.

Kata-Kata Kunci : Konsep Diri, Lingkungan keluarga, Kedisiplinan, Hasil Belajar

\section{ABSTRACT}

This study aims to analyze the influence of self-concept, family environment and discipline of the student learning outcomes of accounting material partially and simultaneously. The population in this study were students of class XI IPS, SMA Antartika Sidoarjo in the academic year of 2013/2014 as many as 180 people, while the number of samples used were 124 people. The data collection techniques were used questionnaires, interviews, and documentation. Analysis method used multiple linear regression techniques. The results showed that selfconcept has no effect on learning outcomes. Family environment and discipline have a significant effect on learning outcomes. Self-concept, family environment, and discipline simultaneously has a significant effect on learning outcomes.
\end{abstract}

Key Words: Self-concept, family environment, Discipline, Learning Outcomes

\section{PENDAHULUAN}

Pendidikan merupakan salah satu komponen yang sangat berperan dalam menentukan nasib suatu bangsa. Keberhasilan dalam bidang pendidikan terus diupayakan oleh pemerintah karena pendidikan merupakan pondasi yang kuat bagi perkembangan negara tersebut. Menurut Langeveld (Pidarta, 2009) Mendidik adalah memberi pertolongan secara sadar dan sengaja kepada anak (yang belum dewasa) dalam pertumbuhannya menuju kearah kedewasaan dalam arti dapat berdiri sendiri dan bertanggung jawab susila atas segala tindakannya menurut 
pilihannya sendiri. Keberhasilan proses belajar diukur melalui hasil belajar. Menurut Theresia (2010) hasil belajar adalah hasil yang diperoleh melalui sebuah kegiatan belajar mata pelajaran tertentu secara mandiri untuk mengetahui seberapa jauh tujuan pembelajaran telah tercapai. Hasil belajar materi akuntansi adalah hasil yang diperoleh melalui sebuah kegiatan belajar materi akuntansi secara mandiri untuk mengetahui seberapa jauh tujuan pembelajaran telah tercapai. Bagi siswa SMA kelas XI IPS materi akuntansi merupakan materi baru yang mereka kenal. Hal ini nampak dalam silabus guru mata pelajaran ekonomi/akuntansi bahwa secara struktur kurikulum pembelajaran akuntansi di SMA masih bergabung dengan mata pelajaran ekonomi dan baru diberikan pada jenjang kelas XI. Hasil Ulangan harian materi akuntansi siswa kelas XI jurusan IPS SMA Antartika Sidoarjo secara keseluruhan belum menunjukkan hasil yang optimal karena masih ada sekitar $41 \%$ siswa harus mengikuti ulangan remedial. Rendahnya hasil belajar materi akuntansi dipengaruhi oleh dua faktor yang meliputi faktor internal dan faktor eksternal. Hal ini didukung dengan pendapat Slameto (2010) yang menyatakan bahwa hasil belajar peserta didik dipengaruhi oleh dua faktor utama yaitu 1) Faktor intern yaitu faktor yang mempengaruhi hasil belajar siswa yang berasal dari dalam dirinya terdiri dari faktor jasmaniah, faktor psikologis dan faktor kelelahan. 2) Faktor ekstern yaitu faktor yang mempengaruhi hasil belajar siswa yang berasal dari luar dirinya terdiri dari keluarga, sekolah dan masyarakat.

Salah satu faktor dari dalam diri siswa yang dapat mendorong siswa untuk meraih hasil belajar adalah konsep diri karena kesadaran siswa untuk belajar sangat erat hubungannya dengan cara pandang siswa terhadap diri mereka sendiri. Menurut Sulastri dan ngadirin (2012) Konsep diri merupakan keyakinan, pandangan, atau penilaian seseorang terhadap dirinya. Brooks dan Memmert (1977) menjelaskan bahwa konsep diri ada dua macam yaitu konsep diri positif dan konsep diri negatif. terdapat perbedaan karakteristik seseorang antara karakteristik diri positif dengan karakteristik diri negatif. Perbedaan tersebut dapat ditunjukkan melalui indikator sebagai berikut: (1) Orang dengan konsep diri positif, dapat dilihat jika mereka: a) yakin akan kemampuan dalam mengatasi masalah; b) merasa setara atau sederajat dengan orang lain; c) menerima pujian tanpa rasa malu; d) menyadari bahwa setiap orang memiliki berbagai perasaan, keinginan dan perilaku yang tidak seluruhnya diterima oleh masyarakat dan e) memiliki kesanggupan dalam mengungkapkan aspek yang tidak disenangi dan berusaha untuk merubahnya. (2) Orang dengan konsep negatif, dapat dilihat jika: a) peka terhadap kritik namun dipersepsi sebagai upaya orang lain untuk menjatuhkan harga dirinya; b) sangat respek terhadap berbagai pujian yang ditujukkan kepada dirinya; c) memiliki kecenderungan bersikap hiperkritis terhadap orang lain; d) merasa tidak senangi dan tidak diperhatikan oleh banyak orang dan e) pesimis terhadap segala yang bersifat kompetitif.

Pencapaian tujuan belajar dengan konsep diri yang positif akan memberikan kontribusi positif jika konsep diri itu diaplikasikan ke dalam suatu tindakan sebaliknya siswa yang belum dapat mengenali dirinya akan merasa sulit untuk menerima segala kelebihan dan kekurangan yang ada pada dirinya sehingga memberikan kontribusi yang negatif. Didukung oleh Efendi (2004) yang menyatakan bahwa pengenalan dan pemahaman serta penilaian terhadap diri sendiri menjadi modal yang sangat berpengaruh bagi siswa untuk mencapai 
prestasi belajar yang diharapkan. Dari beberapa uraian mengenai konsep diri dapat diyakini bahwa konsep diri akan memberikan manajemen yang baik bagi situasi masing-masing individu maupun hubungannya dengan orang lain.

Faktor lingkungan juga sangat berpengaruh terhadap hasil belajar siswa. Salah satu lingkungan di sekitar siswa yang mempunyai peranan tinggi terhadap hasil belajar siswa adalah lingkungan keluarga. Hasbullah (2010) menjelaskan bahwa keluarga merupakan lembaga pendidikan tertua, yang pertama dan utama dialami oleh anak. Kedudukkannya sebagai lembaga pendidikan yang bersifat kodrati menjadikan peranan orang tua memiliki peranan untuk bertanggung jawab memelihara, merawat, melindungi dan mendidik anak agar bisa tumbuh dan berkembang dengan baik. Khafid \& Suroso (2007) menjelaskan bahwa lingkungan keluarga merupakan lingkungan primer yang memiliki pengaruh kuat terhadap individu dibandingkan dengan lingkungan sekunder. Setiap keluarga memiliki cara tersendiri yang berbeda antara keluarga satu dengan lainnya dalam mengasuh, mendidik, dan membimbing anak. Lingkungan keluarga yang menuntut hasil belajar yang tinggi sebagai standar keunggulan anak akan menumbuhkan semangat dan dorongan bagi individu untuk senantiasa mencapai standar keunggulan tersebut.

Lingkungan keluarga berpengaruh dalam perkembangan kepribadian seorang anak. Pentingnya keluarga bagi perkembangan kepribadian siswa karena keluarga memiliki fungsi yang cukup penting. Menurut Soelaiman (1994) fungsi keluarga adalah sebagai berikut; (1) Fungsi edukasi; (2) Fungsi sosialisasi; (3) Fungsi lindungan atau fungsi proteksi; (4) Fungsi afeksi atau fungsi perasaan; (5) Fungsi religious; (6) Fungsi ekonomis; (7) Fungsi rekreasi; dan (8) Fungsi biologis. Kesibukan orang tua siswa terhadap pekerjaannya menyebabkan kurangnya perhatian yang mereka berikan dan cenderung acuh terhadap kegiatan belajar anak. Selain kondisi keluarga yang harmonis, tingkat pendidikan, perhatian, serta pemenuhan kebutuhan belajar anaknya juga merupakan tanggung jawab keluarga (orang tua) dalam mencapai keberhasilan belajar siswa. Di SMA Antartika Masih ditemuinya respon yang kurang dari pihak keluarga ketika anak tidak masuk beberapa hari dan tanpa keterangan. Adanya orang tua siswa yang tidak menghadiri panggilan dari pihak sekolah, misalnya pengambilan rapot ataupun undangan dari pihak sekolah menunjukkan kurangnya peran keluarga terhadap pembelajaran siswa. Slameto (2010) menjelaskan bahwa siswa yang belajar akan menerima pengaruh dari keluarga berupa cara orang tua mendidik, relasi antar anggota keluarga, suasana rumah, keadaan ekonomi keluarga, pengertian orang tua dan latar kebudayaan juga akan berpengaruh terhadap hasil belajar siswa.

Faktor lain yang juga berpengaruh terhadap hasil belajar siswa adalah disiplin. Menurut Moenir (2010) Disiplin merupakan suatu bentuk ketaatan terhadap aturan, baik tertulis maupun tidak tertulis yang telah ditetapkan. Menurut Rokhani (2004) disiplin dalam arti luas yakni: Mencakup setiap macam pengaruh yang ditunjukkan untuk membantu peserta didik agar dia dapat memahami dan menyesuaikan diri dengan tuntutan lingkungannya dan juga penting tentang cara menyelesaikan tuntutan yang mungkin ingin ditujukan peserta didik terhadap lingkungannya. Disiplin siswa menurut Yudhawati dan Dany (2011) berarti kepatuhan dan ketaatan siswa terhadap berbagai aturan dan tata tertib yang berlaku disekolahnya. 
Menurut Arisana (2012) Indikator kedisiplinan meliputi ketaatan terhadap tata tertib sekolah, ketaatan terhadap kegiatan belajar disekolah, ketaatan dalam mengerjakan tugas-tugas pelajaran dan ketaatan terhadap kegiatan belajar dirumah. Sedangkan Tu'u (2004) menjabarkan pendapat Maman Rachman akan pentingnya disiplin bagi para siswa diantaranya meliputi: 1) Memberi dukungan bagi terciptanya perilaku yang tidak menyimpang; 2) Membantu siswa memahami dan menyesuaikan diri dengan tuntutan lingkungan; 3) Cara menyelesaikan tuntutan yang ingin ditunjukkan peserta didik terhadap lingkungannya; 4) Untuk mengatur keseimbangan keinginan individu satu dengan individu lainnya; 5) Menjauhi siswa melakukan hal-hal yang dilarang sekolah.

Disiplin merupakan kesediaan untuk memenuhi peraturan-peraturan dan larangan-larangan. Kepatuhan disini bukan hanya patuh karena adanya tekanantekanan dari luar melainkan kepatuhan yang didasari oleh adanya kesadaran tentang nilai dan pentingnya peraturan-peraturan dan larangan tersebut. Di SMA Antartika Sidoarjo pelanggaran yang sering dilakukan siswa diantaranya meliputi terlambat datang ke sekolah, seragam yang tidak lengkap, menyontek ketika ujian, tidak mengerjakan tugas, tidur pada saat KBM, dan siswa yang ramai saat mengikuti pelajaran. Kedisiplinan harus dijalankan dengan konsisten, teratur dan jelas sesuai dengan peraturan tata tertib yang telah ditetapkan, sehingga siswa akan terbiasa hidup dengan teratur. Dengan adanya tata tertib siswa maka setiap tindakan dan perilaku siswa akan dikontrol, sehingga kedisiplinan siswa disekolah dapat tercipta.

Pentingnya penelitian ini dilakukan adalah untuk mengetahui dan mengkaji lebih dalam tentang pengaruh konsep diri, lingkungan keluarga dan kedisiplinan siswa, yang pada akhirnya dapat diketahui faktor dominan yang mempengaruhi hasil belajar materi akuntansi siswa. Sehingga dapat menjadi bahan masukan bagi berbagai pihak khususnya sekolah dan keluarga guna meningkatkan hasil belajar siswa.

\section{METODE PENELITIAN}

Pendekatan yang digunakan dalam penelitian ini adalah pendekatan kuantitatif sedangkan variabel dalam penelitian ini adalah konsep diri $\left(\mathrm{X}_{1}\right)$, lingkungan keluarga $\left(\mathrm{X}_{2}\right)$ dan kedisiplinan siswa $\left(\mathrm{X}_{3}\right)$ sebagai variabel independen, dan hasil belajar (Y) sebagai variabel dependen. Populasi dalam penelitian ini adalah seluruh siswa kelas XI Jurusan IPS, SMA Antartika Sidoarjo yang berjumlah 180 siswa. Sedangkan sampel penelitian ditentukan dengan menggunakan rumus slovin dengan alfa 5\% dan diperoleh ukuran sampel sebesar 124. Teknik sampling yang digunakan dalam penelitian ini menggunakan teknik propotional random sampling.

Metode pengumpulan data yang digunakan dalam penelitian ini adalah Angket, wawanara dan dokumentasi. Kuesioner yang digunakan mengungkap variabel konsep diri, lingkungan keluarga dan kedisiplinan siswa. Metode analisis data yang digunakan dalam penelitian ini adalah analisis deskriptif dan regresi berganda. Analisis deskriptif digunakan untuk mengetahui kondisi konsep diri, lingkungan keluarga, kedisiplinan dan hasil belajar siswa. Sedangkan analisis regresi digunakan untuk mengetahui besarnya hubungan antara variabel bebas dengan variabel terikat baik secara parsial maupun secara simultan. 


\section{HASIL PENELITIAN DAN PEMBAHASAN}

\section{Hasil Penelitian}

Berdasarkan uji normalitas data, nilai Kolmogorov Smirnov Z sebesar 0,032 dengan tingkat signifikan 0,160 , berarti hal itu menunjukkan bahwa model regresi terdistribusi normal karena tingkat signifikansinya $\geq 0,05$. Hasil Uji Multikolinearitas diperoleh hasil bahwa nilai VIF pada seluruh variabel bebas lebih kecil dari 10, artinya seluruh variabel bebas pada penelitian ini tidak ada gejala multikolinier. Hasil uji Heteroskedastisitas nilai signifikansinya untuk variabel konep diri, lingkungan keluarga dan kedisiplinan lebih dari 5\%, ini berarti bahwa tidak ada hubungan ketiga variabel bebas dengan nilai residunya, maka dapat disimpulkan tidak terdapat gejala heteroskedastisiitas pada penelitian ini. Uji Linieritas dilakukan dengan menggunakan Lagrange Multiplier, hasil uji linearitasnya diketahui nilai C $(42,408)<146,57$, maka dapat dikatakan linier.

Model regresi yang diperoleh berdasarkan hasil penelitian dapat dituliskan dalam bentuk persamaan regresi sebagai berikut:

$$
Y=67,825+2,805 X_{1}+1,269 X_{2}+4,852 X_{3}
$$

Berdasarkan persamaan regresi tersebut ketiga variabel bebas memiliki koefisien regresi dengan arah positif. Hal ini berarti semakin baik konsep diri, lingkungan keluarga dan kedisiplinan maka semakin baik hasil belajar. Dari persamaan tersebut diatas dapat dijelaskan sebagai berikut : 1) Konstanta sebesar 67,825 menunjukkan besarnya pengaruh konsep diri $\left(\mathrm{X}_{1}\right)$, lingkungan keluarga $\left(\mathrm{X}_{2}\right)$, dan kedisiplinan $\left(\mathrm{X}_{3}\right)$ terhadap hasil belajar $(\mathrm{Y})$, apabila variabel bebas tersebut tidak berubah, maka diprediksikan hasil belajar sebesar 67,825 satuan. 2) Koefisien regresi untuk konsep diri $\left(\mathrm{X}_{1}\right)$ sebesar 2,805. Berarti jika konsep diri $\left(\mathrm{X}_{1}\right)$ naik sebesar 1 satuan, maka hasil belajar (Y) akan mengalami kenaikan sebesar 2,805 satuan, dengan anggapan variabel bebas lainnya tetap. 3) Koefisien regresi untuk lingkungan keluarga $\left(\mathrm{X}_{2}\right)$ sebesar 1,269. Berarti jika lingkungan keluarga $\left(\mathrm{X}_{2}\right)$ naik sebesar 1 satuan, maka hasil belajar (Y) akan mengalami peningkatan sebesar 1,269 satuan, dengan anggapan variabel bebas lainnya tetap. 4) Koefisien regresi untuk kedisiplinan $\left(X_{3}\right)$ sebesar 4,852. Berarti jika kedisiplinan $\left(\mathrm{X}_{3}\right)$ naik sebesar 1 satuan, maka hasil belajar (Y) akan mengalami kenaikan sebesar 4,852 satuan, dengan anggapan variabel bebas lainnya tetap.

Pengujian variabel konsep diri $\left(\mathrm{X}_{1}\right)$, lingkungan keluarga $\left(\mathrm{X}_{2}\right)$, dan kedisiplinan $\left(\mathrm{X}_{3}\right)$ terhadap hasil belajar $(\mathrm{Y})$ secara simultan berpengaruh signifikan terhadap hasil belajar. Hasil uji $\mathrm{F}$ berdasarkan uji ANOVA atau uji statistik F, model menunjukkan bahwa nilai Fhitung yaitu 63,1992 dengan nilai signifikansi 0,000 lebih kecil dari tingkat signifikansi $(\alpha) 0,05$, sehingga dapat disimpulkan bahwa konsep diri $\left(\mathrm{X}_{1}\right)$, lingkungan keluarga $\left(\mathrm{X}_{2}\right)$, dan kedisiplinan $\left(\mathrm{X}_{3}\right)$ secara simultan (bersamaan) mempunyai pengaruh nyata terhadap hasil belajar (Y).

Berdasarkan hasil uji F, Nilai koefisien determinasi (adjusted $R$ Square) yaitu sebesar 0,6027, ini menunjukkan bahwa besarnya kontribusi antara variabel bebas yaitu konsep diri $\left(\mathrm{X}_{1}\right)$, lingkungan keluarga $\left(\mathrm{X}_{2}\right)$, dan kedisiplinan $\left(\mathrm{X}_{3}\right)$ secara simultan menjelaskan perubahan variasi dari variabel terikat hasil belajar (Y) sebesar 60,27 \% sedangkan sisanya sebesar 39,73\% dijelaskan oleh variabel lain. Nilai t-hitung diketahui sebagai berikut: 
1. Variabel konsep diri sebesar 1,5958 dengan tingkat signifikan lebih dari 5\% yaitu 0,1132. Hal ini menunjukkan bahwa konsep diri secara parsial tidak berpengaruh signifikan terhadap hasil belajar siswa

2. Variabel lingkungan keluarga sebesar 5,7235 dengan tingkat signifikan kurang dari 5\% yaitu 0,000 pada variabel lingkungan keluarga. Hal ini berarti bahwa lingkungan keluarga secara parsial berpengaruh signifikan terhadap hasil belajar materi akuntansi siswa Besarnya pengaruh lingkungan keluarga terhadap hasil belajar dapat dilihat dari nilai $\mathrm{r}^{2}$ yaitu sebesar 0,2145 yang berarti besarnya pengaruh lingkungan keluarga terhadap hasil belajar materi akuntansi sebesar $21,45 \%$.

3. Variabel kedisiplinan siswa sebesar 7,9360 dengan tingkat signifikan kurang dari 5\% yaitu 0,000 pada variabel kedisiplinan. Hal ini berarti bahwa kedisiplinan secara parsial berpengaruh signifikan terhadap hasil belajar materi akuntansi siswa. Besarnya pengaruh kedisiplinan terhadap hasil belajar dapat dilihat dari nilai $\mathrm{r}^{2}$ yaitu sebesar 0,3442 yang berarti besarnya pengaruh kedisiplinan terhadap hasil belajar materi akuntansi sebesar $34,42 \%$.

\section{Pembahasan}

\section{Pengaruh Konsep Diri, Lingkungan Keluarga dan Kedisiplinan siswa terhadap hasil belajar materi akuntansi}

Berdasarkan pengujian dengan analisis regresi linier berganda variabel konsep diri $\left(\mathrm{X}_{1}\right)$, lingkungan keluarga $\left(\mathrm{X}_{2}\right)$ dan kedisiplinan $\left(\mathrm{X}_{3}\right)$ secara bersamasama mempunyai pengaruh yang signifikan terhadap hasil belajar (Y) Siswa kelas XI Jurusan IPS SMA Antartika Sidoarjo tahun pelajaran 2013-2014. Hal ini menunjukkan jika seorang siswa memiliki konsep diri, Lingkungan Keluarga dan kedisiplinan yang tinggi maka hasil belajar juga akan menjadi tinggi. Penelitian ini mendukung penelitian Khafid dan suroso (2007), yang menyimpulkan bahwa secara bersama-sama disiplin belajar lingkungan keluarga berpengaruh signifikan terhadap hasil belajar ekonomi.

Hasil penelitian ini mendukung hasil penelitian Budi, dkk (2011) yang menyatakan secara statistik tidak terdapat terdapat pengaruh konsep diri peserta didik terhadap hasil belajar.

Hasil penelitian ini tidak mendukung hasil penelitian yang dilakukan oleh Sulastri dan Ngadirin (2012), Yoshino (2012) dan Awan (2011) Toni dkk (2013) dan Rensi dan Sugiarti (2010) yang menunjukkan bahwa semakin baik konsep diri positif yang dimiliki siswa maka hasil belajar juga akan semakin meningkat sebaliknya semakin rendah konsep diri positif yang dimiliki siswa maka hal tersebut juga akan berpengaruh terhadap hasil belajar siswa yang rendah

Berdasarkan hasil penelitian diketahui bahwa lingkungan keluarga berpengaruh signifikan terhadap hasil belajar materi akuntansi. Hasil penelitian ini mendukung hasil penelitian terdahulu yang dilakukan oleh Mohanraj and latha (2005), Codjoe and Dalton (2007) dan Mishra and veena (2012), yang menjelaskan bahwa faktor keluarga memainkan peranan yang cukup penting dalam tercapainya hasil belajar yang maksimal.

Berdasarkan hasil penelitian diketahui bahwa kedisiplinan berpengaruh signifikan terhadap hasil belajar materi akuntansi. Penelitian ini mendukung penelitian yang dilakukan oleh Luiselli et al (2005), Sukawijaya (2010) dan Arisana dan Ismani (2012) menjelaskan bahwa penanganan masalah 
ketidakdisiplinan yang terjadi akan memberikan dampak positif pada hasil belajar siswa. Sukawijaya (2010), dalam penelitiannya menyimpulkan bahwa terdapat kontribusi yang positif dan signifikan antara kedisiplinan diri terhadap hasil belajar.

Konsep diri secara simultan berpengaruh terhadap hasil belajar hal ini didukung oleh temuan bahwa pada dasarnya seluruh siswa SMA Antartika telah mempunyai konsep diri yang terbagi dalam konsep diri tinggi dan konsep diri rendah. siswa yang berkonsep diri rendah namun berhasil memperoleh nilai belajar materi akuntansi tinggi disebabkan karena para siswa berusaha dengan berbagai cara untuk menyempurnakan diri (Soemanto, 2006). Saat para siswa memperoleh nilai jelek, siswa berusaha dengan belajar lebih giat lagi untuk menyempurnakan diri guna memperoleh nilai yang lebih bagus dan pada kenyataannya yang dilakukan oleh para siswa berkonsep diri rendah cukup berhasil. Selain itu siswa yang berkonsep diri rendah, mengacu pada Desmita (2009) memiliki dimensi harapan atau diri yang dicita-citakan dimasa depan cukup tinggi. Siswa yang berkonsepsi diri rendah masih mempunyai harapan untuk selalu belajar dan tidak akan mengulangi perolehan hasil belajar yang jelek. Hal itu dibuktikan pada saat siswa mengalami kesulitan mereka tidak segan untuk bertanya kepada guru pada saat jam istirahat ataupun pulang sekolah dan kegiatan diskusi dengan teman ketika siswa mengalami kesulitan.

Berdasarkan hasil penelitian diketahui bahwa lingkungan keluarga berpengaruh signifikan terhadap hasil belajar materi akuntansi. Pada penelitian ini menunjukkan, Fungsi edukasi yaitu fungsi keluarga yang berkaitan dengan pendidikan anak khususnya dan pendidikan serta pembinaan anggota keluarga pada umumnya mempunyai peran yang paling penting.

Berdasarkan hasil penelitian diketahui bahwa kedisiplinan berpengaruh signifikan terhadap hasil belajar materi akuntansi. Ketaatan terhadap kegiatan belajar di sekolah, ketaatan terhadap tata tertib disekolah dan ketaatan dalam mengerjakan tugas-tugas pelajaran dan ketaatan terhadap kegiatan belajar dirumah merupakan faktor yang mempengaruhinya.

\section{Pengaruh Konsep Diri Terhadap Hasil Belajar}

Berdasarkan hasil analisis regresi linier berganda diperoleh hasil bahwa secara statistik Konsep Diri $\left(\mathrm{X}_{1}\right)$ terbukti tidak berpengaruh terhadap hasil belajar materi akuntansi (Y) siswa kelas XI jurusan IPS SMA Antartika Sidoarjo Tahun pelajaran 2013 - 2014. Hal ini menunjukkan jika seorang siswa memiliki konsep diri yang tinggi maka hasil belajar siswa belum tentu akan tinggi begitu juga sebaliknya siswa yang memiliki konsep diri rendah hasil belajarnya juga tidak selalu rendah.

Hasil penelitian ini mendukung hasil penelitian Budi, dkk (2011) yang menyatakan bahwa tidak terdapat perbedaan yang signifikan antara hasil belajar peserta didik yang berkonsep diri tinggi dibandingkan dengan peserta didik yang berkonsep diri rendah. Secara statistik dapat dinyatakan tidak terdapat terdapat pengaruh konsep diri peserta didik terhadap hasil belajar.

Hasil penelitian ini tidak mendukung hasil penelitian yang dilakukan oleh Rensi dan Sugiarti (2010) yang menunjukkan bahwa semakin baik konsep diri positif yang dimiliki siswa maka hasil belajar juga akan semakin meningkat sebaliknya semakin rendah konsep diri positif yang dimiliki siswa maka hal 
tersebut juga akan berpengaruh terhadap hasil belajar siswa yang rendah. Hasil penelitian ini juga tidak mendukung hasil penelitian yang dilakukan Toni dkk (2013) yang menyimpulkan bahwa konsep diri yang dimiliki oleh siswa memiliki hubungan yang positif dan signifikan terhadap hasil belajar.

Temuan yang terjadi di SMA Antartika Sidoarjo siswa yang memiliki konsep diri rendah dan memiliki hasil belajar tinggi lebih banyak daripada siswa yang memiliki konsep diri rendah dengan hasil belajar rendah. Siswa yang berkonsep diri rendah namun berhasil memperoleh nilai belajar materi akuntansi tinggi karena para siswa berusaha dengan berbagai cara untuk menyempurnakan diri. Keyakinan siswa SMA Antartika untuk mendapatkan nilai yang lebih baik dari sebelumnya ditunjukkan dari kemauan siswa untuk memperbaiki nilai dengan belajar lebih giat lagi artinya saat para siswa memperoleh nilai yang kurang memuaskan, siswa berusaha untuk memperbaiki nilai menjadi lebih baik dari yang sebelumnya dengan mengerjakan tugas-tugas yang diberikan guru sebaik mungkin serta berusaha mencari tahu terhadap hal-hal yang berkaitan dengan materi pelajaran yang belum mereka pahami dari berbagai sumber. Pada kenyataannya yang dilakukan oleh para siswa berkonsep diri rendah cukup berhasil.

\section{Pengaruh Lingkungan Keluarga Terhadap Hasil Belajar}

Berdasarkan hasil analisis regresi linier berganda diperoleh hasil bahwa secara statistik Lingkungan Keluarga $\left(\mathrm{X}_{2}\right)$ terbukti berpengaruh signifikan terhadap hasil belajar materi akuntansi (Y) siswa kelas XI jurusan IPS SMA Antartika Sidoarjo Tahun pelajaran 2013 - 2014. Hal ini menunjukkan jika seorang siswa memperoleh dukungan yang tinggi dalam keluarga maka hasil belajar juga akan menjadi tinggi dan begitu juga sebaliknya.

Hasil penelitian ini mendukung hasil penelitian terdahulu yang dilakukan oleh Mohanraj and Latha (2005) yang Menyimpulkan bahwa faktor keluarga memainkan peranan yang cukup penting dalam penyesuaian remaja dan prestasi akademik. Penelitian Codjoe and Dalton (2007) dan Slameto (2010) juga menyatakan bahwa faktor keluarga memainkan peranan yang cukup penting dalam penyesuaian diri remaja dan hasil belajar. Hasil penelitian ini sesuai dengan pernyataan Khafid \& Suroso (2007) bahwa lingkungan keluarga merupakan lingkungan primer yang memiliki pengaruh kuat terhadap individu dan berpengaruh dalam perkembangan kepribadian seorang anak.

Hasil penelitian ini lebih menunjukkan fungsi edukasi dalam sebuah keluarga. Menurut Soelaiman (1994) fungsi edukasi yaitu fungsi keluarga yang berkaitan dengan pendidikan anak khususnya dan pendidikan serta pembinaan anggota keluarga pada umumnya mempunyai peran yang paling penting. Fungsi edukasi ini tidak sekedar menyangkut pelaksanaan tetapi menyangkut pula penentuan dan pengukuraan landasan yang mendasari upaya pendidikan yaitu pengarahan dan perumusan tujuan pendidikan, perencanaan dan pengolahannya, penyediaan sarana dan prasarana dan pengayaan wawasannya.

Fungsi pendidikan yang dilakukan oleh keluarga kepada anak dapat diketahui dari sikap orang tua yang banyak membantu dan mengarahkan ketika anaknya mengalami kesulitan dan teguran orang tua ketika anaknya dirumah tidak belajar. Keberhasilan fungsi pendidikan dalam lingkungan keluarga akan memberikan pengalaman dalam berinteraksi dengan lingkungan keluarga. 
Pengalaman inilah sebagai suatu proses usaha yang dilakukan siswa untuk memperoleh suatu perubahan tingkah laku yang baru secara keseluruhan.

Menurut Soelaiman (1994), Kurangnya perhatian keluarga terhadap siswa menunjukkan menurunnya fungsi afeksi yaitu komunikasi anak dengan lingkungan dan keluarganya dengan keseluruhan pribadinya. Kurangnya perhatian keluarga bisa dipersepsikan oleh siswa kurangnya kasih sayang orang tua pada anaknya sehingga hal tersebut akan mempengaruhi suasana rumah dan berdampak pada hasil belajar siswa. Namun hal ini dapat diatasi dengan keterbukaan anak ketika mengalami kesulitan belajar, sehingga orang tua dapat membantu untuk memecahkan permasalahan yang dialami oleh anak dalam kesulitan belajar.

Fungsi pendidikan yang dilakukan oleh keluarga kepada siswa di SMA Antartika Sidoarjo dapat diketahui dari sikap orang tua yang banyak membantu dan mengarahkan ketika anaknya mengalami kesulitan dan teguran orang tua ketika anaknya dirumah tidak belajar. Tingkat pendidikan atau kebiasaan didalam keluarga dapat mempengaruhi sikap anak dalam belajar. Hal ini ditunjukkan dari hasil temuan bahwa keluarga membiasakan siswa untuk tekun dan rajin belajar serta memberi dukungan dan motivasi kepada siswa agar bisa mencapai pendidikan setinggi-tingginya. Dukungan keluarga juga dapat ditunjukkan lewat kemauan orang tua siswa dalam memantau perkembangan belajar siswa baik dirumah maupun disekolah dengan melakukan komunikasi dengan guru.

\section{Pengaruh Kedisplinan Terhadap Hasil Belajar}

Berdasarkan hasil analisis regresi linier berganda diperoleh hasil bahwa secara statistik Kedisiplinan $\left(\mathrm{X}_{3}\right)$ terbukti berpengaruh signifikan terhadap hasil belajar materi akuntansi (Y) siswa kelas XI jurusan IPS SMA Antartika Sidoarjo Tahun pelajaran 2013 - 2014. Hal ini menunjukkan jika seorang siswa mempunyai tingkat kedisiplinan yang tinggi maka hasil belajar juga akan menjadi tinggi dan begitu juga sebaliknya.

Hasil penelitian ini mendukung hasil penelitian terdahulu yang dilakukan oleh Arisana dan Ismani (2012), Sukawijaya (2010) dan Luiselli et al. (2005) yang mengatakan bahwa variabel disiplin mempunyai korelasi terhadap prestasi akademik. Penanganan masalah ketidakdisiplinan yang terjadi memberi dampak positif pada hasil belajar siswa. Diyakini kedisiplinan berpengaruh terhadap hasil belajar siswa, dengan disiplin siswa akan memiliki kecakapan mengenai cara belajar yang baik.

Ketaatan dalam mengerjakan tugas dilakukan oleh siswa dengan mengerjakan tugas dari guru dengan baik, mengumpulkan tugas yang diberikan dari guru dengan tepat waktu, mengerjakan tugas kelompok dengan penuh tanggung jawab. Mengerjakan tugas merupakan rangkaian kegiatan dalam belajar, yang dilakukan di dalam maupun di luar jam pelajaran sekolah. Tugas itu mencakup pengerjaan PR, menjawab soal latihan dari guru, soal dalam buku pegangan, ulangan harian, ulangan umum dan ujian (Slameto, 2003). Hasil penelitian ini menunjukkan bahwa siswa mampu melakukan disiplin perbuatan yaitu tidak malas belajar (Diar Rudyanto, 2010). Faktor psikologis (Sulastri dan Ngadirin 2012) yang terdiri dari kecerdasan, motivasi, minat, persepsi siswa, kebiasaan belajar sangat berperan dalam menentukan keberhasilan belajar materi akuntansi. 
Ketaatan terhadap kegiatan belajar dirumah rendah. Hal ini karena kurangnya kesadaran siswa untuk belajar dirumah tanpa disuruh orang tua/anggota keluarga lainnya. Hasil penelitian ini menunjukkan bahwa masih pentingnya faktor ekstern yaitu dorongan keluarga untuk meningkatkan hasil belajar siswa. Kedisiplinan dalam segala hal terutama dalam belajar hendaknya dimiliki oleh setiap anak, yang akhirnya dapat menjadi kebiasaan dalam setiap aktivitasnya. Apabila cara belajar yang teratur dan disiplin itu sudah menjadi kebiasaan, maka akan terbentuk etos belajar yang baik. Di mana kewajiban belajar bukan lagi menjadi beban melainkan sudah dianggap sebagai kebutuhan hidupnya

Siswa SMA Antartika Sidoarjo mengikuti pelajaran dengan tertib serta membawa buku-buku pelajaran sesuai dengan jadwal yang sudah ada. Ketaatan ini akan membantu siswa dalam mengikuti pelajaran materi akuntansi yang ada. Dengan mengikuti pelajaran secara tertib siswa tidak akan ketinggalan informasi yang disampaikan oleh guru selain itu siswa juga bisa menanyakan hal-hal yang mugkin kurang dia pahami begitu juga membawa buku pelajaran yang dijadwalkan akan membuat siswa bisa mengikuti pelajaran dengan baik.

\section{KESIMPULAN}

Hasil penelitian yang sudah di lakukan oleh peneliti dapat di simpulkan bahwa: Tidak ada pengaruh Konsep diri terhadap hasil belajar materi akuntansi siswa SMA Antartika Sidoarjo. Hal ini berarti siswa yang memiliki konsep diri tinggi tidak selalu diikuti dengan hasil belajar yang baik pula begitu juga sebaliknya; Ada pengaruh lingkungan keluarga terhadap hasil belajar materi akuntansi siswa SMA Antartika Sidoarjo. Hal ini berarti semakin baik kondisi lingkungan keluarga akan diikuti dengan hasil belajar yang baik pula; Ada pengaruh kedisiplinan terhadap hasil belajar materi akuntansi siswa SMA Antartika Sidoarjo. Hal ini berarti semakin tinggi kedisiplinan yang dimiliki siswa maka akan berpengaruh terhadap peningkatan hasil belajar siswa; Ada pengaruh konsep diri, lingkungan keluarga dan kedisiplinan siswa terhadap hasil belajar materi akuntansi siswa SMA Antartika Sidoarjo. Hal ini menunjukan bahwa konsep diri, lingkungan keluarga dan kedisiplinan siswa secara simultan berpengaruh signifikan terhadap hasil belajar siswa. Konsep diri dan lingkungan keluarga yang baik serta kedisiplinan yang tinggi akan semakin meningkatkan hasil belajar siswa.

\section{DAFTAR RUJUKAN}

Arisana, Arga Lacopa dan Ismani. 2012. "Pengaruh Kedisiplinan Siswa dan Persepsi tentang Kualitas Mengajar Guru terhadap Prestasi Belajar Akuntansi Siswa Kelas XI IPS MAN Yogyakarta II Tahun Ajaran 2011/2012”. Jurnal Pendidikan Akuntansi: Universitas Negeri Yogyakarta.

Awan, dkk. 2011. "A Study of Relationship between Achievement Motivation,

Self Concept and Achievement in English and Mathematics at Secondary Level”. International Education Studies Vol.4, No 3. 2011

Brooks, W.D. dan P.Emmert. 1977. Interpersonal Communication. Dubuque: Wm.C. Brown Company Publishers. 
Budi, Rosa Candra,dkk. 2011. "Pengaruh Metode Partisipatif dan Konsep Diri terhadap Hasil Belajar IPS pada Program Paket B”. Tekno-Pedagogi Vol.1. Universitas Jambi.

Codjoe and Dalton. 2007. "The Importance of Home Environment and Parental Encouragement in the Academic Achievement of African Canadian Youth". Canadian Journal Of Education. 30,1

Desmita. 2009. Psikologi Perkembangan Peserta Didik. Bandung: PT Remaja Rosdakarya.

Efendi, Kusno. 2004. "Hubungan antara Konsep Diri dan Kemampuan Verbal dengan Prestasi Belajar pada Siswa Kelas Lima Sekolah Dasar Muhammadiyah Sukonando Yogyakarta". Fakultas Psikologi: Universitas Ahmad Dahlan.

Hasbullah. 2010. Dasar-dasar Ilmu Pendidikan. Jakarta: PT Raja Grafindo Persada.

Khafid, Muhammad \& Suroso. 2007. "Pengaruh Disiplin Belajar dan Lingkungan Pidarta, Made. 2009. Landasan Kependidikan. Jakarta: Rineka cipta.

Luiselli, James K, et al. 2005. "Whole-school Positive Behavior Support: Effects on Student Discipline Problems and Academic Performace". Educational Psychology Vol 25 Nos 2-3, April-june. 2005

Mishra, Sandhya and Veena Bamba. 2012. "Impact of family Environment on Academic Achievement of Secondary School Students in Science Subject". IJRESS Volume 2, Issue 5. 2012

Moenir, Has. 2010. Manajemen Pelayanan Umum di Indonesia. Jakarta:Bumi Aksara.

Mohanraj, Rani and latha. 2005. "perceived family environment in relation to adjustment and academic Achievement". Journal of the Indian Academy of Applied Psychology Vol 31. 2005

Rensi dan Lucia Rini Sugiarti. 2010. "Dukungan Sosial, Konsep Diri dan Prestasi Belajar Siswa SMP Kristen YSKI Semarang”. Fakultas Psikologi: Universitas katolik SoegijapranataKeluarga terhadap Hasil Belajar Ekonomi" Fakultas Ekonomi: Universitas Negeri Semarang.

Rokhani, Ahmad dan Abu Ahmadi. 2004. Pengelolaan Pengajaran. Jakarta: Rineka Cipta.

Slameto. 2010. Belajar dan Faktor-faktor yang Mempengaruhinya. Jakarta: Rineka Cipta.

Soelaiman, MI. 1994. Pendidikan Dalam Keluarga. Bandung: Alfabeta.

Soemanto, Wasty. 2006. Psikologi Pendidikan. Jakarta:Rineka Cipta

Sukawijaya, I Wayan. 2010. "Kontribusi Hasil Belajar Seni Rupa, Kedisiplinan Diri dan Motivasi Berprestasi terhadap Hasil Belajar Komputer Grafis Siswa Program Keahlian Multimedia SMK Negeri 2 Sukawati”. Tesis. Pascasarjana Universitas Ganesha Singaraja.

Sulastri, Susi Sri \& Ngadirin Setiawan. 2012. "Pengaruh Konsep diri dan kebiasaan belajar akuntansi siswa kelas XI IPS Madrasah Aliyah Negeri Yogyakarta II Tahun Ajaran 2011/2012”. Kajian Pustaka Akuntansi Indonesia. Universitas Negeri Yogyakarta.

Theresia L. \& Tanwey. G.R. 2011. Penilaian Hasil Belajar pada Tingkat Satuan Pendidikan”. Unesa Uneversity Press. 
Toni, Kantun dkk .2013. "Determinasi Konsep diri, motivasi berprestasi dan disiplin belajar IPA SD Se-Kecamatan Buleleng”. E-journal program pascasarjana Universitas Pendidikan Ganesha: Volume 3 Tahun 2013.

Tu'u, Tulus. 2004. "Peran Disiplin pada Perilaku dan Prestasi Siswa”. Jakarta: Grasindo.

Yoshino, 2012. "The Relationship between Self-Concept and Achievement in TIMSS 2007: A Comparison between American and Japanese Students". Int Rev Education. 2012.

Yudhawati, Ratna dan Danny Haryanto. 2011. "Teori-teori Dasar Psikologi Pendidikan”. Jakarta: PT. Prestasi Pustakaraya. 